\title{
Psychological factors influencing delayed diagnosis for breast cancer patients
}

\author{
Mara Jidveian Popescu, ${ }^{1,2}$ Otilia-Elena Surdu², Maria Daniela Tanasescu行, Irina Nita ${ }^{2,4}$, \\ Loredana Sabina Cornelia Manolescu², Adela Ciobanu ${ }^{5,6}$ \\ ${ }^{1}$ CF2 Clinical Hospital, Bucharest, Romania \\ 2"Carol Davila" University of Medicine, Bucharest, Romania \\ ${ }^{3}$ Department of Nephrology, University Emergency Hospital, Bucharest, Romania \\ ${ }^{4}$ Medical Oncology Department, Elias University Emergency Hospital, Bucharest, Romania, \\ ${ }^{5}$ Department of Psychiatry, "Carol Davila" University of Medicine, Bucharest, Romania \\ 6"Prof. Dr. Alexandru Obregia" Psychiatry Hospital, Bucharest
}

\begin{abstract}
Background. In Romania there is a discrepancy between breast cancer incidence (the 22 place in Europe) and mortality rate (the 8th place in Europe), probably determined by late diagnosis. The study aims to find associations between the delayed diagnosis in breast cancer and a series of socio-psychological and medical characteristics of the patients.

Methods. 101 breast cancer patients were administered a battery of tests for depression, anxiety, stress, coping mechanism, social support, social status, medical and family history and the time between first symptoms and diagnosis. Inclusion criteria were age over 18 years old, pathologic confirmation of breast cancer, at least one type of oncologic treatment (surgery, radiotherapy, chemotherapy, hormonal therapy and/or targeted therapy). Exclusion criteria were altered general status, untreated brain metastases, spatial temporal disorientation, decompensated psychiatric comorbidity, severe pain.

Results. Delayed presentation was positively correlated with both the age of the patients $(p=0.031)$ and age at diagnosis $(p=0.017)$, medical history $(p=0.048)$, low use of refocusing on planning coping style $(p=0.042)$. Conclusions. Coping styles, medical history of chronic illness influence delayed diagnosis of breast cancer, which is potentially contributing to a bad prognosis. Further longitudinal studies and screening procedures could contribute to a better understanding of the individual contribution of these factors to delayed diagnosis.
\end{abstract}

Keywords: breast cancer, late diagnosis, psychologic factors

\section{BACKGROUND}

Breast cancer incidence has significantly increased in the last two decades in Europe and in Romania. Regarding incidence rate for breast cancer in women, Romania is below the European average, with 113.1 vs. 143 cases per 100,000 inhabitants, but the mortality rate is higher than the European average, with 36.2 vs 34.1 deaths per 100,000 inhabitants, Romania being on the eight place in Europe regarding breast cancer mortality rate (1).

A possible reason for the difference between incidence and mortality rate for breast cancer pa- tients is late diagnosis caused by either deficiency in the medical system (deficiency in screening and prevention programs, limited access to modern diagnostic methods) or by late presentation of the patients caused by psychological impairment (poor coping mechanisms - denial; depression, severe anxiety) (2-9).

\section{AIM OF THE STUDY}

The study aims to find associations between the delayed diagnosis in breast cancer and a series of socio-psychological and medical characteristics of the patients. 


\section{METHOD}

Between September 2018 and May 2019, a battery of tests was administered to 101 patients with breast cancer who were being treated at the Oncology Department of CF2 Clinical Hospital in Bucharest. The battery included questions regarding marital status, medical history, family history of oncologic disease, types of therapy they had for the current cancer, initial and current symptoms, the time between first signs and symptoms and the first medical consult. For psychological characteristics we investigated self-esteem with Rosenberg's Self-Esteem Scale (10 item questionnaire regarding positive and negative feelings about self (10)), perceived social support by using the DUKE questionnaire (a 10 item questionnaire regarding help and empathy from other people (11)), the level of depression, anxiety and perceived stress with DASS 21-R questionnaire for psychiatric comorbidity (a 21 item questionnaire that evaluates levels of depression, anxiety and stress -7 items each (12)) and coping mechanisms with the Cognitive-Emotional Coping questionnaire were used (a 36 item questionnaire that includes 9 types of coping used in negative settings: self-blame, acceptance, rumination, positive refocusing, refocusing on planning, putting into perspective, catastrophizing, blaming others (13)).

The inclusion criteria for patients were age -18 years old, pathologic confirmation of breast cancer, at least one type of oncologic treatment (surgery, radiotherapy, chemotherapy, hormonal therapy and/or targeted therapy).

Exclusion criteria: breast cancer patients with altered general status (ECOG 3-4), untreated brain metastases, spatial temporal disorientation, decompensated psychiatric comorbidity, severe pain.

The study was approved by the hospital's ethic commission and the participants signed an informed consent. The data was statistically analyzed with SPSS 22.0 for windows by using T test, ANOVA, Chi-Square test.

\section{RESULTS}

From the 101 questionnaires distributed, 96 were female (95\%). Because of the high difference in the number of female and male patients it was decided to do statistical analyze only on the female subgroup. The age distribution was 35 to 81 years old, with average 51.66 and median of 51 , standard deviation 10.5. Division into age groups was unequal, $32.3 \%$ were $51-60$ years old, followed by $41-50$ years old $(30.2 \%), 31-40$ years old (18.8\%),
$61-70$ years old $(11.5 \%)$ and over 70 years old $7,3 \%$. Most of the patients were from urban areas (74\%), married $(83.3 \%)$ and with children $(87.5 \%-$ $47.9 \% 1$ child, $39.6 \%$ at least 2 children).

More than half of the patients presented medical history of chronic illness (52\%), 46.9\% had positive family history of oncologic disease and $31.2 \%$ had relatives that died of oncologic disease.

By analyzing the responses from the questionnaires, it was shown that $86.5 \%$ had medium levels of self-esteem, $76 \%$ reported high levels of perceived social support, $30.6 \%$ had medium and severe signs of depression, $69.8 \%$ showed medium and high levels of anxiety and $42.7 \%$ had medium and high levels of perceived stress (Table 1).

TABLE 1. Repartition of the responses for Rosenberg's Self-Esteem Scale, DUKE questionnaire and DASS 21-R questionnaire for psychiatric comorbidity

\begin{tabular}{|l|c|c|c|}
\hline \multicolumn{1}{|c|}{ Value } & Low/normal & Medium & High \\
\hline Self esteem & $1 \%$ & $86.5 \%$ & $12.5 \%$ \\
\hline Perceived social support & $3.1 \%$ & $20.8 \%$ & $76 \%$ \\
\hline Depression & $59.4 \%$ & $26 \%$ & $14.6 \%$ \\
\hline Anxiety & $30.2 \%$ & $29.2 \%$ & $40.6 \%$ \\
\hline Perceived stress & $57.3 \%$ & $30.2 \%$ & $12.5 \%$ \\
\hline
\end{tabular}

Regarding the use of coping mechanisms, most frequently (over 65\%) the patients reported the use of acceptance $(75 \%)$, putting into perspective $(67.7 \%)$ and catastrophizing $(82.3 \%)$ (Table 2).

TABLE 2. Coping mechanism

\begin{tabular}{|l|c|c|c|}
\hline \multicolumn{1}{|c|}{ Coping mechanism } & High usage & $\begin{array}{c}\text { Medium } \\
\text { usage }\end{array}$ & $\begin{array}{c}\text { Low } \\
\text { usage }\end{array}$ \\
\hline Self-blame & $54.2 \%$ & $30.2 \%$ & $15.6 \%$ \\
\hline Acceptance & $75 \%$ & $18.8 \%$ & $5.2 \%$ \\
\hline Rumination & $53.1 \%$ & $31.3 \%$ & $15.6 \%$ \\
\hline Positive refocusing & $61.5 \%$ & $24 \%$ & $14.5 \%$ \\
\hline Refocusing on planning & $49 \%$ & $34.4 \%$ & $16.6 \%$ \\
\hline Positive reevaluation & $62.4 \%$ & $18.8 \%$ & $18.8 \%$ \\
\hline Putting into perspective & $67.7 \%$ & $17.7 \%$ & $14.6 \%$ \\
\hline Catastrophizing & $82.3 \%$ & $8.3 \%$ & $9.4 \%$ \\
\hline Blaming others & $36.5 \%$ & $41.7 \%$ & $21.8 \%$ \\
\hline
\end{tabular}

The time between first signs and symptoms of illness and first medical consult was divided in 4 groups - under 1 month, 1-6 months, 6-12 months and over 1 year. Most patients declared they had their first medical consult in the first 6 months $(67.7 \%)$, followed by patients that presented for the first consult in 6 to 12 months $(16.67 \%)$ and $15.63 \%$ declared they waited for more than 1 year.

After analyzing the correlation between the time between first signs and symptoms of illness and first medical consult and general and psychologic factors, it was showed that there is a correla- 
tion between the age of the patients and time to diagnosis. There is a tendency for the patients with ages between 40 and 60 years old to ask for medical consult in over 3 months from first signs and symptoms $(55 \%)$ and for patients with ages over 60 years old in less than 3 months (55.6\%), without a linearity of the relation but with statistical signification $(\mathrm{p}=0.31)$ (Table 3$)$.

TABLE 3. Correlation between time to diagnostic and age of the patients

\begin{tabular}{|l|r|r|r|}
\hline & \multicolumn{1}{|c|}{ Value } & \multicolumn{1}{c|}{ df } & \multicolumn{2}{|c|}{$\begin{array}{c}\text { Asymptotic } \\
\text { Significance (2-sided) }\end{array}$} \\
\hline $\begin{array}{l}\text { Pearson Chi- } \\
\text { Square }\end{array}$ & $22.582 \mathrm{a}$ & 12 & .031 \\
\hline Likelihood Ratio & 24.200 & 12 & .019 \\
\hline $\begin{array}{l}\text { Linear-by-Linear } \\
\text { Association }\end{array}$ & .031 & 1 & .860 \\
\hline N of valid cases & 96 & & \\
\hline
\end{tabular}

There was also a statistically significant correlation between time to diagnostic and the age of the patients at diagnostic $(p=0.017)$ (Table 4). There is a tendency for the patients with ages between 40 and 50 years old to ask for medical consult in over 3 months from first signs and symptoms $(61 \%)$ and for patients with ages 50 to 60 years old in less than 3 months (64\%), without a linearity of the relation.

TABLE 4. Correlation between time to diagnostic and age at diagnostic

\begin{tabular}{|l|r|r|r|}
\hline & \multicolumn{1}{|c|}{ Value } & \multicolumn{1}{c|}{ df } & \multicolumn{2}{c|}{$\begin{array}{c}\text { Asymptotic } \\
\text { Significance (2-sided) }\end{array}$} \\
\hline Pearson Chi-Square & $24.507 a$ & 12 & .017 \\
\hline Likelihood Ratio & 22.707 & 12 & .030 \\
\hline Linear-by-Linear & .251 & 1 & .616 \\
Association & & & \\
\hline N of valid cases & 96 & & \\
\hline
\end{tabular}

A long time to diagnostic is associated with the lack of comorbidities $(p=0.048)$ (Table 5), patients with no comorbidities tend to present to first medical consult in over 3 months and the ones with known comorbidities in less than 3 months, with strong linearity of the correlation.

TABLE 5. Correlation between time to diagnostic and presence of comorbidities

\begin{tabular}{|l|r|r|r|}
\hline & \multicolumn{1}{|c|}{ Value } & \multicolumn{1}{c|}{ df } & \multicolumn{2}{c|}{$\begin{array}{c}\text { Asymptotic } \\
\text { Significance (2-sided) }\end{array}$} \\
\hline Pearson Chi-Square & \multicolumn{1}{|c|}{$17.058 \mathrm{a}$} & 9 & .048 \\
\hline Likelihood Ratio & 22.154 & 9 & .008 \\
\hline $\begin{array}{l}\text { Linear-by-Linear } \\
\text { Association }\end{array}$ & 5.216 & 1 & .022 \\
\hline N of valid cases & 96 & & \\
\hline
\end{tabular}

Regarding coping mechanism used by patients, there was statistically significant correlation between refocusing on planning and time to diagnostic $(p=0.042)($ Table 6$)$. The patients with high usage of the coping style tend to present in more than 3 months (57\%), and the ones with low usage present in less than 3 months (75\%). Patients with medium usage of the coping style were equally distributed between over and under 3 months. The correlation showed linearity.

TABLE 6. Correlation between time to diagnostic and refocusing on planning

\begin{tabular}{|l|r|r|r|}
\hline & \multicolumn{1}{|c|}{ Value } & \multicolumn{1}{c|}{ df } & \multicolumn{2}{|c|}{$\begin{array}{c}\text { Asymptotic } \\
\text { Significance (2-sided) }\end{array}$} \\
\hline Pearson Chi-Square & $13,061 \mathrm{a}$ & 6 &, 042 \\
\hline Likelihood Ratio & 12,709 & 6 &, 048 \\
\hline $\begin{array}{l}\text { Linear-by-Linear } \\
\text { Association }\end{array}$ & 2,827 & 1 &, 093 \\
\hline N of valid cases & 96 & & \\
\hline
\end{tabular}

There were no significant statistical correlations between time to diagnostic and self-esteem, depression, anxiety and perceived stress in this group of patients.

\section{DISCUSSIONS}

This study analyzed the correlation between psychosocial characteristics of breast cancer patients and late presentation for diagnostic. There were 101 patients enrolled in the study (5 men and 96 women). The number of male patients respects the distribution of male cancer patients in the general population (5\%) (14).

Because of the small number of male breast cancer patients enrolled in the study (5 patients $4.9 \%$ ), it was not possible to do a statistical analyze by gender. It has to be taken into consideration an increase of the incidence of male breast cancer in the last decade $(15,16)$, requiring significant attention in terms of early diagnosis and treatment, given that breast cancer in men has a significantly worse prognosis (15). An important element associated with the late diagnosis of these patients is stigma related to the disease, which aggravates the symptoms of anxiety, perceived stress and depression. Studies show that $25 \%$ of the patient's present signs of severe depression $(17,18)$, and $24 \%$ clinically manifested anxiety disorder (19).

The average age of the patients was 51.66, standard deviation 10.5 , this being with more than 10 years younger than declared average age for breast cancer patients (62 years) (20). A possible explanation for the age difference is the reticence of older patients to respond to questionnaires. 
According to data from literature, self-esteem varies throughout the treatment of breast cancer patients. After surgery, the level of self-esteem is high (21). There is also a difference between patients who had sectorectomy or mastectomy followed by reconstruction versus the ones with mastectomy, who have lower self-esteem (22).

The high levels of perceived social support found in our group are in concordance with the data found in literature. A lower perceived social support is associated with patients that are single and with low performance status $(23,24)$.

The levels of depression, anxiety and perceived stress found in this group of patients similar with the data found in the literature, that show a lower level of depression and perceived stress and a high level of anxiety (24-27).

Regarding the use of coping mechanisms, the patients enrolled in the study reported the frequent use of acceptance $(75 \%)$, putting into perspective $(67.7 \%)$ and catastrophizing $(82.3 \%)$. These results are partially sustained by data in literature, where there is reported a high usage of acceptance, positive reevaluation, religious coping, humor and venting of emotions (28-30).

The majority of the patients had their first medical consult in the first 6 months. The results are sustained by data from literature, that shows the majority of breast cancer patients get diagnosed in less than 3 months from the appearance of first signs and symptoms $(31,32)$.

The data we found in the literature shows a correlation between the age of the patients, but in other studies an older age is associated with late diag-

\section{REFERENCES}

1. ECIS - European Cancer Information System. Available at: https:// ecis.jrc.ec.europa.eu.

2. Al-Azri MH. Delay in Cancer Diagnosis: Causes and Possible Solutions. Oman Med J. 2016 Sep;31(5):325-6.

3. Allgar VL, Neal RD. Delays in the diagnosis of six cancers: analysis of data from the National Survey of NHS Patients: Cancer. $\mathrm{Br} J$ Cancer. 2005 Jun 6;92(11):1959-70.

4. Ambusaidi A, Al-Balushi S. Health Education in The Sultanate of Oman. In: Taylor N, Quinn F, Littledyke M, Coll RK (eds.). Health Education in Context. Rotterdam: SensePublishers, 2012.

5. Green T, Atkin K, Macleod U. Cancer detection in primary care: insights from general practitioners. Br J Cancer. 2015 Mar 31;112 Suppl 1(Suppl 1):S41-9.

6. Jones R, Latinovic R, Charlton J, Gulliford MC. Alarm symptoms in early diagnosis of cancer in primary care: cohort study using General Practice Research Database. BMJ. 2007 May 19;334(7602):1040.

7. Koyi H, Hillerdal G, Brandén E. Patient's and doctors' delays in the diagnosis of chest tumors. Lung Cancer. 2002 Jan;35(1):53-7.

8. Jidveian Popescu M, Ciobanu A. Factors Influencing Delayed Diagnosis in Oncology. Maedica (Bucur). 2020 Jun;15(2):191-195.

9. Niță I, Nițipir C, Toma ȘA, Limbău AM, Pîrvu E, Bădărău IA, Suciu I, Suciu G, Manolescu LSC. Histological Aspects and Quantitative nosis (31). The difference between the results found in this study and data found in the literature could be explained by the small sample of patients in the study or by a difference between characteristics of the population of Romania and other countries. In order to clarify this result, it is necessary to include in the study a larger population of breast cancer patients.

There aren't sufficient data in the literature regarding the correlation between coping strategies and late presentation of breast cancer patients. Most studies show a correlation between emotional coping strategies and the expression of emotion with better survival, regardless of the stage of disease at diagnosis (33-40).

The study's limitations were given by the reduced number of patients enrolled, especially male patients. Also, by enrolling patients from a hospital in Bucharest, the percentage of patients from the rural areas was relatively small.

\section{CONCLUSIONS}

This study shows that age, absence of comorbidities and coping strategies are a part of the characteristics that prone breast cancer patients to prolong time to medical consult. Knowing this, it is important to educate younger women regarding the importance of periodical self-evaluation of the breast, participating to screening programs for breast cancer and asking for medical consult every time they observe a modification of the breast or axilla.

Assessment of Ki67 as Prognostic Factors in Breast Cancer Patients: Result from a Single-Center, Cross Sectional Study. Medicina (Kaunas). 2020 Nov 9;56(11):600.

10. Rosenberg M. Society and the Adolescent Self-Image. Princeton University Press, 1965.

11. Koenig HG, Westlund RE, George LK, Hughes DC, Blazer DG, Hybels C. Abbreviating the Duke Social Support Index for use in chronically ill elderly individuals. Psychosomatics. 1993 Jan-Feb; 34(1):61-9.

12. Lovibond SH, Lovibond PF, Perțe A, Albu M, DASS Manual pentru Scalele de depresie, anxietate și stress - DASS 21-R. Adaptarea și standardizarea DASS pe populația din România. COGNITROM, Cluj-Napoca, 2011.

13. Garnefski N, Kraaij V, Spinhoven P, Perțe A, Chestionarul de coping emotional-cognitiv CERQ. Adaptarea și standardizarea pe populația din România, COGNITROM, Cluj-Napoca, 2010.

14. Bray F, Ferlay J, Soerjomataram I, Siegel RL, Torre LA, Jemal A. Global cancer statistics 2018: GLOBOCAN estimates of incidence and mortality worldwide for 36 cancers in 185 countries. CA Cancer J Clin. 2018 Nov;68(6):394-424.

15. Diez Freire CC. Male breast carcinoma - general. Available at: http:// www.pathologyoutlines.com/topic/breastmalignantmalecarcinoma.html. 
16. Cutuli B, Le-Nir CC, Serin D, Kirova Y, Gaci Z, Lemanski C, De Lafontan B, Zoubir M, Maingon P, Mignotte H, de Lara CT, Edeline J, Penault-Llorca F, Romestaing P, Delva C, Comet B, Belkacemi Y. Male breast cancer. Evolution of treatment and prognostic factors. Analysis of 489 cases. Crit Rev Oncol Hematol. 2010 Mar;73(3):246-54.

17. Massie MJ. Prevalence of depression in patients with cancer. J Natl Cancer Inst Monogr. 2004;(32):57-71.

18. Tsaras K, Papathanasiou IV, Mitsi D, Veneti A, Kelesi M, Zyga S, Fradelos EC. Assessment of Depression and Anxiety in Breast Cancer Patients: Prevalence and Associated Factors. Asian Pac J Cancer Prev. 2018 Jun 25;19(6):1661-1669.

19. Kadan-Lottick NS, Vanderwerker LC, Block SD, Zhang B, Prigerson HG. Psychiatric disorders and mental health service use in patients with advanced cancer: a report from the coping with cancer study. Cancer. 2005 Dec 15;104(12):2872-81.

20. Noone AM, Cronin KA, Altekruse SF, Howlader N, Lewis DR, Petkov VI, Penberthy L. Cancer Incidence and Survival Trends by Subtype Using Data from the Surveillance Epidemiology and End Results Program, 1992-2013. Cancer Epidemiol Biomarkers Prev. 2017 Apr;26(4):632-641.

21. Veiga DF, Veiga-Filho J, Ribeiro LM, Archangelo I Jr, Balbino PF, Caetano LV, Novo NF, Ferreira LM. Quality-of-life and self-esteem outcomes after oncoplastic breast-conserving surgery. Plast Reconstr Surg. 2010 Mar;125(3):811-7.

22. Markopoulos C, Tsaroucha AK, Kouskos E, Mantas D, Antonopoulou Z, Karvelis S. Impact of breast cancer surgery on the self-esteem and sexual life of female patients. J Int Med Res. 2009 Jan-Feb; 37(1):182-8.

23. Thompson T, Rodebaugh TL, Pérez M, Schootman M, Jeffe DB. Perceived social support change in patients with early stage breast cancer and controls. Health Psychol. 2013 Aug;32(8):886-95.

24. Ng CG, Mohamed S, See MH, Harun F, Dahlui M, Sulaiman AH, Zainal NZ, Taib NA; MyBCC Study group. Anxiety, depression, perceived social support and quality of life in Malaysian breast cancer patients: a 1-year prospective study. Health Qual Life Outcomes. 2015 Dec 30;13:205

25. Zainal NZ, Nik-Jaafar NR, Baharudin A, Sabki ZA, Ng CG. Prevalence of depression in breast cancer survivors: a systematic review of observational studies. Asian Pac J Cancer Prev. 2013;14(4):2649-56.

26. Burgess C, Cornelius V, Love S, Graham J, Richards M, Ramirez A. Depression and anxiety in women with early breast cancer: five year observational cohort study. BMJ. 2005 Mar 26;330(7493):702.

27. Fann JR, Thomas-Rich AM, Katon WJ, Cowley D, Pepping M, McGregor BA, Gralow J. Major depression after breast cancer: a review of epidemiology and treatment. Gen Hosp Psychiatry. 2008 Mar-Apr;30(2):112-26.

28. Stanton AL, Danoff-Burg S, Cameron CL, Bishop M, Collins CA, Kirk SB, Sworowski LA, Twillman R. Emotionally expressive coping predicts psychological and physical adjustment to breast cancer. $J$ Consult Clin Psychol. 2000 Oct;68(5):875-82.

29. Carver CS, Pozo C, Harris SD, Noriega V, Scheier MF, Robinson DS, Ketcham AS, Moffat FL Jr, Clark KC. How coping mediates the effect of optimism on distress: a study of women with early stage breast cancer. J Pers Soc Psychol. 1993 Aug;65(2):375-90.

30. Compas BE, Stoll MF, Thomsen AH, Oppedisano G, Epping-Jordan $\mathrm{JE}, \mathrm{Krag} \mathrm{DN}$. Adjustment to breast cancer: age-related differences in coping and emotional distress. Breast Cancer Res Treat. 1999 Apr;54(3):195-203.

31. Arndt V, Stürmer T, Stegmaier C, Ziegler H, Dhom G, Brenner H. Patient delay and stage of diagnosis among breast cancer patients in Germany - a population based study. Br J Cancer. 2002 Apr 8;86(7):1034-40.

32. Coates RJ, Bransfield DD, Wesley M, Hankey B, Eley JW, Greenberg RS, Flanders D, Hunter CP, Edwards BK, Forman M, et al. Differences between black and white women with breast cancer in time from symptom recognition to medical consultation. Black/White Cancer Survival Study Group. J Natl Cancer Inst. 1992 Jun 17;84(12):938-50.

33. Reynolds P, Hurley S, Torres M, Jackson J, Boyd P, Chen VW. Use of coping strategies and breast cancer survival: results from the Black/ White Cancer Survival Study. Am J Epidemiol. 2000 Nov 15;152(10):940-9.

34. Tampa M, Mitran Cl, Mitran MI, Nicolae I, Dumitru A, Matei C, Manolescu L, Popa GL, Caruntu C, Georgescu SR. The Role of Beta HPV Types and HPV-Associated Inflammatory Processes in Cutaneous Squamous Cell Carcinoma. J Immunol Res. 2020 Apr 6;2020:5701639.

35. Dragomirescu CC, Lixandru BE, Coldea IL, Corneli ON, Pana M, Palade AM, Cristea VC, Suciu I, Suciu G, Manolescu LSC, Popa LG, Popa MI. Antimicrobial Susceptibility Testing for Corynebacterium Species Isolated from Clinical Samples in Romania. Antibiotics (Basel). 2020 Jan 16;9(1):31.

36. Manolescu LSC, Boeru C, Căruntu C, Dragomirescu CC, Goldis M, Jugulete G, Marin M, Popa GL, Preda M, Radu MC, Popa MI. A Romanian experience of syphilis in pregnancy and childbirth. Midwifery. 2019 Nov;78:58-63.

37. Dragomirescu CC, Lixandru BE, Coldea IL, Corneli ON, Pana M, Palade AM, Cristea VC, Suciu I, Suciu G, Manolescu LSC, Popa LG, Popa MI. Antimicrobial Susceptibility Testing for Corynebacterium Species Isolated from Clinical Samples in Romania. Antibiotics (Basel). 2020 Jan 16;9(1):31.

38. Manolescu L, Marinescu P. Sex differences in HIV-1 viral load and absolute CD4 cell count in long term survivors HIV-1 infected patients from Giurgiu, Romania. Romanian Review of Laboratory Medicine. 2013;21(2).

39. Marinescu P, Manolescu LSC. Association of hepatitis B infection in patients with HIV Encephalopathy. Romanian Biotechnological Letters. 2012;17(6):7817-24.

40. Manolescu L, Temereanca A, Diaconu CC, Ruta S. Correlation between resistance profile and immunosuppression in heavily treated HIV-1 infected Romanian patients. Romanian Biotechnological Letters. 2011;16(4):6439-49. 